\title{
Pelatihan Aplikasi Screen Recorder dan Video Conference Guna Meningkatkan Proses Belajar Mengajar
}

\author{
Triana Elizabeth*1, Dicky Pratama ${ }^{2}$, Derry Alamsyah $^{3}$, Yoannita $^{4}$, Inayatullah ${ }^{5}$, \\ Tinaliah ${ }^{6}$, \\ trianaelizabeth@mdp.ac.id*1 \\ ${ }^{1,2}$ Sistem Informasi, Ilmu Komputer \& Rekayasa, Universitas Multi Data Palembang \\ ${ }^{3,4}$ Teknik Informatika, Ilmu Komputer \& Rekayasa, Universitas Multi Data Palembang \\ 5,6 Manajemen Informatika, Ilmu Komputer \& Rekayasa, Universitas Multi Data Palembang
}

\author{
Received: 24 Mei 2021 \\ Accepted: 7 Juni $2021 \quad$ Online Published: 31 Juli 2021 \\ DOI: 10.29408/ab.v2i1.3495 \\ URL: http://dx.doi.org/10.29408/ab.v2i1.3495
}

\begin{abstract}
Abstrak: Di awal tahun 2020, Indonesia menghadapi pandemi virus Covid 19. Akibatnya terjadinya perubahan di segala sektor, termasuk bidang pendidikan. Perubahan model pembelajaran dari luring ke daring membuat masyarakat menjadi kesulitan, karena tidak terbiasa menggunakan teknologi digital dalam belajar. Oleh karena itu, kegiatan pengabdian ini bertujuan untuk melatih 10 guru TK Dewi Sartika Palembang menggunakan aplikasi video conference (Google Meet) dan perekam layar (AZ Screen Recorder) agar dapat mendukung proses pembelajaran yang lebih optimal. Kegiatan ini dilaksanakan dengan menerapkan protokol kesehatan. Berdasarkan hasil evaluasi kegiatan pelatihan maka diperoleh hasil bahwa sетиa guru telah татри menggunakan aplikasi Google Meet dan AZ Screen Recorder serta mampu membuat video pembelajaran dan menggunakannya dalam proses belajar. Akan tetapi banyak siswa tidak dapat mengikuti proses pembelajaran daring karena terhalang sinyal internet yang kurang baik. Hal ini dapat diatasi dengan mengirimkan hasil rekaman proses pembelajaran yang telah direkam melalu aplikasi perekam layar.
\end{abstract}

Kata Kunci: AZ Screen Recorder; Google Meet; Covid-19; Media Pembelajaran; Video Conference

\begin{abstract}
At the beginning of 2020, Indonesia faced the Covid-19 virus pandemic. As a result, changes occurred in all sectors, including the education sector. The change in the learning model from offline to online makes it difficult for Indonesian because they are not accustomed to using digital technology in the learning process. Therefore, this service activity aims to train 10 Dewi Sartika Palembang Kindergarten teachers using video conferencing applications (Google Meet) and screen recorders (AZ Screen Recorder) to support a more optimal learning process. This activity is carried out by implementing health protocols. Based on the results of the evaluation of the training activities, it was obtained that all teachers were able to use the Google Meet and AZ Screen Recorder applications and were able to make learning videos and use them in the learning process. However, many students cannot participate in the online learning process because of poor internet signals. This problem can be overcome by sending a video recording of the learning process.
\end{abstract}

Keyword: AZ Screen Recorder; Google Meet; Covid-19; Learning Medium; Video Conference 
Elizabet, T., Pratama, D., Alamsyah, D., Yoannita, Y., Inayatullah, I., \& Tinaliah, T. (2021). Pelatihan aplikasi screen recorder dan video conference guna meningkatkan proses belajar mengajar. ABSYARA: Jurnal Pengabdian Pada Masyarakat, 2(1), 49-55. doi:10.29408/ab.v2i1.3495

\section{PENDAHULUAN}

Pada awal tahun 2020 seluruh negara di dunia menghadapi penyakit Covid-19 yang diakibatkan oleh virus Corona. Sampai sekarang penyakit ini masih belum ditemukan obatnya dan pandemi ini terus meluas dan semakin banyak orang yang terjangkit virus ini. Adanya wabah virus ini menyebabkan pemerintah Indonesia memberlakukan pembatasan sosial dalam skala besar (PSBB) bagi daerah - daerah yang terjangkit penyakit ini termasuk kota Palembang. Dampak dari diberlakukannya PSBB dalam dunia pendidikan salah satunya adalah menyebabkan banyak sekolah yang harus menerapkan pembelajaran daring atau pembelajaran dari rumah. Berdasarkan surat edaran walikota (2020) No 8/SE/Dinkes/2020 maka sekolah menghentikan kegiatan belajar siswa di sekolah dan menerapkan metode pembelajaran jarak jauh/daring tersebut selama masa pandemi COVID-19 sampai ada ketentuan lebih lanjut dari Pemerintah. Salah satu sekolah yang menerapkan pembelajaran daring/online untuk peserta didiknya adalah TK Dewi Sartika Palembang.

Dengan adanya pembelajaran daring baik dalam bentuk interaksi dua arah atau semi dua arah dapat berjalan dengan dinamis (Maulah \& Ummah, 2020). Salah satu instrumen dalam proses pembelajaran daring adalah media pembelajaran. Media pembelajaran sendiri merupakan perantara atau penghubunga antara sumber informasi dan penerima informasi (Tafonao, 2018). Media pembelajaran sendiri dapat berupa gambar, suara, video, artikel, dan lain-lain yang memiliki tujuan instruksional atau memiliki maksud-maksud tertentu. Suatu media pembelajaran yang baik harus bersifat interaktif (Arianti, 2020). Bentuk dari media pembelajaran interaktif biasanya berupa produk layanan digital yang dapat merespon input atau tindakan pengguna, contohnya seperti aplikasi game dan lain sebagainya (Yudianto, 2017).

Menurut Fahruddin dan Astini (2018) perkembangan otak anak di awal tahun perkembangnya dipengaruhi oleh keadaan lingkungan di sekitarnya. Agar perkembangan dan pertumbuhan anak dapat tercapai secara optimal diperlukan stimulasi dan kondisi lingkungan yang sesuai dengan kebutuhan anak tersebut. Perkembangan potensi anak di usia 4-6 tahun tidak lepas dari peran pendidik, baik orang tua, guru dan orang dewasa di sekitarnya. Menurut Zaini dan Dewi (2017) melalu permainan, seorang anak dapat memiliki kesempatan untuk menemukan, mengeksploitasi, mengekspresikan, berkreasi dan belajar dengan menyenangkan, sehingga anak tersebut lebih dapat mengenal dirinya sendiri, orang lain, dan lingkungannya. Oleh sebab itu banyak orang tua yang memasukkan anaknya di sekolah taman kanak-kanak (TK)

TK Dewi Sartika adalah yayasan pendidikan taman kanak-kanak yang berada di jalan Kesatria, RT 70, RW 02, Sukajaya, Sukarami, Kota Pelembang, Sumatra Selatan. Saat ini, para pengajar TK Dewi Sartika sedikit kesulitan dalam proses transformasi pembelajaran yang biasanya dilakukan dengan siswa pada ruang kelas di sekolah menjadi penerapan pembelajaran daring/ online. Dalam kegiatan pembelajaran jarak jauh ini, biasanya mereka berkomunikasi dengan orang tua siswa melalui media aplikasi pesan WhatsApp. Melalui aplikasi WhatsApp mereka bisa melakukan video call dalam suatu group call, hanya saja jumlah peserta video call menggunakan aplikasi WhatsApp ini terbatas. Selain itu, aplikasi WhatsApp juga tidak dapat 
Elizabet, T., Pratama, D., Alamsyah, D., Yoannita, Y., Inayatullah, I., \& Tinaliah, T. (2021). Pelatihan aplikasi screen recorder dan video conference guna meningkatkan proses belajar mengajar. ABSYARA: Jurnal Pengabdian Pada Masyarakat, 2(1), 49-55. doi:10.29408/ab.v2i1.3495

menampilkan presentasi/ gambar/ video secara langsung dan tidak mempunyai fitur untuk dapat melakukan perekaman video call yang berlangsung. Selain itu, para pengajar sedikit mengalami kesulitan dalam membuat materi pembelajaran yang menarik secara daring/online agar murid-murid dapat lebih mudah memahami pelajaran yang biasanya disampaikan di sekolah sekarang disampaikan secara online.

Oleh sebab itu, kami tim dosen Universitas Multi Data Palembang berbagi pengetahuan melalui pengadaan pelatihan singkat untuk memperkenalkan aplikasi Google Meet sebagai media dalam melakukan conference atau pembelajaran online dan aplikasi AZ Screen Recorder yang digunakan untuk membuat video pembelajaran yang menarik sehingga dapat meningkatkan proses belajar mengajar. Pelatihan ini dilaksanakan secara luring bersama para pengajar dan orang tua siswa/i TK Dewi Sartika Palembang dengan tetap mengikuti protokol kesehatan yang berlaku.

Aplikasi AZ Screen Recorder dipilih sebagai aplikasi pembuatan video pembelajaran karena dikutip dari (AZ Screen Recorder for Android - APK Download, n.d.) AZ Screen Recorder merupakan sebuah aplikasi yang berguna untuk merekam semua hal yang terjadi di layar perangkat smartphone ke video FullHD dan QHD, dan juga satu-satunya aplikasi perekam layar di Play Store yang dapat dijeda dan dimulai lagi ketika perekaman. Selain itu terdapat fitur merekam suara dari mic, menampilkan sentuhan layar, memilih resolusi video, frame-rate dan bit-rate, menghitung waktu mundur, menampilkan teks dan logo, menyimpan video ke kartu SD, memilih time-lapse atau gerakan lambat. Fitur-fitur ini lah yang dirasa cocok bagi pengajar TK Dewi Sartika untuk membuat video pembelajaran.

Sedangkan aplikasi Google Meet dipilih sebagai aplikasi media video conference dikarenakan dikutip dari (Google Meet (Sebelumnya Hangouts Meet) - Rapat Video Gratis, n.d.)_aplikasi google meet ini memiliki banyak fitur yang bisa dimanfaatkan untuk kegiatan pembelajaran. Fitur pada google meet dapat diakses secara gratis yaitu bisa mengundang 100 peserta, tidak dibatasi waktu, aman dikarenakan pengguna wajib melakukan login ke akun google terlebih dahulu dan dapat dijalankan pada web browser seperti chrome tanpa perlu ada aplikasi tambahan untuk desktop, serta terdapat juga beberapa fitur seperti raise hand, dan record pertemuan yang pasti secara gratis juga.

Banyak manfaat dengan dilakukan pelatihan ini dimana sebelumnya ada hasil yang dirasakan dari pelatihan-pelatihan sejenis yang sebelumnya telah dilaksanakan, beberapa diantaranya yaitu hasil pelatihan media pembelajaran kepada guru-guru yayasan pendidikan Muhammad Syatir Al-Ghazali Tangerang Selatan yang dilakukan oleh (Faradiba, dkk., 2019) adalah pengetahuan guru-guru TK meningkat dilihat dari peningkatan kreativitas dalam menciptakan media pembelajaran sains serta penyajian materi dan cara mengajar guru juga meningkat. Pelatihan lain yang dilakukan oleh Samsuri, taufik, dkk yaitu pelatihan desain interaktif pada pembelajaran daring bagi dosen pendidikan biologi, hasil dari pelatihan yang dilakukan adalah para peserta memiliki pengetahuan dan keteranpilan dalam mendesain media interaktif pada pembelajaran daring (Samsuri, dkk., 2020). Hasil lainnya adalah dengan mengembangkan media pembelajaran interaktif melalui pemanfaatan video conference pada 
Elizabet, T., Pratama, D., Alamsyah, D., Yoannita, Y., Inayatullah, I., \& Tinaliah, T. (2021). Pelatihan aplikasi screen recorder dan video conference guna meningkatkan proses belajar mengajar. ABSYARA: Jurnal Pengabdian Pada Masyarakat, 2(1), 49-55. doi:10.29408/ab.v2i1.3495

mata pelajaran produktif jurusan agribisnis tanaman di SMK Negeri 2 Prabumulih, melalui metode observasi hasilnya adalah rata rata penilaian aktivitas guru terhadap penggunaan media berada pada kategori sangat efektif (Subekti, dkk., 2020)

\section{METODE PELAKSANAAN}

\section{Waktu dan Lokasi}

Pelatihan dilaksanakan pada pada hari Sabtu, tanggal 21 November 2020 dan berjalan selama kurang lebih tiga jam mulai pukul 09.00 di TK Dewi Sartika Palembang.

\section{Prosedur pelaksanaan}

Sebelum pelaksanaan, tim pengabdian melakukan peninjauan ke lokasi dan melakukan diskusi bersama kepala sekolah TK Dewi Sartika tentang proses pembelajaran yang ada di sekolah dan kendala-kendala yang dialami serta solusi-solusi untuk mengatasi kendala tersebut. Selanjutnya tim melakukan diskusi internal, lalu melakukan koordinasi tentang waktu, tempat, para peserta, serta persiapan lainnya demi kelancaran pelatihan aplikasi screen recorder dan video conference.

Para peserta dari kegiatan pelatihan ini adalah semua pengajar, beberapa siswa dan orang tua atau wali siswa TK Dewi Sartika Palembang yang berlokasi di Jalan Kesatria, RT 70, RW 02, Sukajaya, Sukarami, Kota Pelembang, Sumatra Selatan. Mereka telah diberikan pelatihan singkat mengenai menggunakan aplikasi Google Meet dan aplikasi AZ Video Screen Recorder yang dilakukan oleh tim. Pelatihan ini dilaksanakan secara langsung berlokasi di TK Dewi Sartika Palembang pada hari Sabtu, tanggal 21 November 2020 dan berjalan selama kurang lebih tiga jam mulai pukul 09.00. Dikarenakan kondisi kota Palembang yang masih menghadapi penyakit Covid-19 serta adanya imbauan dari Pemerintah untuk mengurangi jumlah yang berkumpul atau kontak langsung, maka kegiatan ini akan dilaksanakan dengan membatasi jumlah peserta yang mengikuti pelatihan dan menerapkan physical distancing serta menggunakan masker

\section{HASIL DAN PEMBAHASAN HASIL}

Kegiatan pelatihan ini telah dilaksanakan di TK Dewi Sartika Palembang yang berlokasi di Jalan Kesatria, RT 70, RW 02, Sukajaya, Sukarami, Kota Pelembang, Sumatra Selatan. Dikarenakan kota Palembang masih berada di zona merah untuk Covid-19, maka kegiatan pengabdian ini dilangsungkan dengan mengikuti protokol kesehatan dimana peserta pelatihan dan seluruh anggota tim menggunakan masker selama pelatihan berlangsung. Pelatihan berjalan lancar dimana ada interaksi antara instructor dan para peserta dan para peserta sanggup mengikuti apa yang dijelaskan yang berkaitan dengan pembuatan video menggunakan AZ screen recorder dan video conference menggunakan aplikasi google meet.

Pelatihan dilakukan dengan metode praktek langsung yang diawali dengan kata sambutan oleh kepala sekolah TK Dewi Sartika Palembang dan perwakilan tim pengabdian kemudian dilanjutkan dengan sesi pelatihan aplikasi AZ screen recorder lalu sesi pelatihan aplikasi Google Meet. Sesi pelatihan aplikasi AZ Screen Recorder dimulai dengan pengenalan 
Elizabet, T., Pratama, D., Alamsyah, D., Yoannita, Y., Inayatullah, I., \& Tinaliah, T. (2021). Pelatihan aplikasi screen recorder dan video conference guna meningkatkan proses belajar mengajar. ABSYARA: Jurnal Pengabdian Pada Masyarakat, 2(1), 49-55. doi:10.29408/ab.v2i1.3495

aplikasi, instalasi aplikasi AZ Screen Recorder, penjelasan fitur-fitur aplikasi AZ Screen Recorder, praktek langsung pembuatan video pembelajaran menggunakan aplikasi tersebut dan cara mengunggah video pembelajaran yang dihasilkan ke youtube serta cara melakukan share link video youtube ke grup WhatsApp kelas. Setelah pelatihan penggunaan aplikasi AZ Screen Recorder, dilanjutkan dengan sesi pelatihan penggunaan aplikasi video conference yaitu Google Meet dimulai dari instalasi aplikasi Google Meet di smart phone, pengenalan aplikasi Google Meet, penjelasan cara membuat meet room di browser laptop dan juga smart phone serta penjelasan dan praktek langsung fitur-fitur yang terdapat pada aplikasi Google Meet seperti menyalakan dan mematikan mikrofon, fitur raise hand, fitur mengganti kamera depan dengan kamera belakang maupun sebaliknya, cara merekam video yang sedang berlangsung dan cara keluar dari aplikasi google meet. Selama penjelasan atau praktek langsung, peserta diperbolehkan untuk bertanya langsung. Berikut gambar atau foto selama pelatihan berlangsung. Gambar 1 merupakan foto saat pelatihan aplikasi AZ Screen Recorder dilangsungkan (kiri) dan foto saat pelatihan aplikasi Google meet menggunakan smartphone dan komputer (kanan).

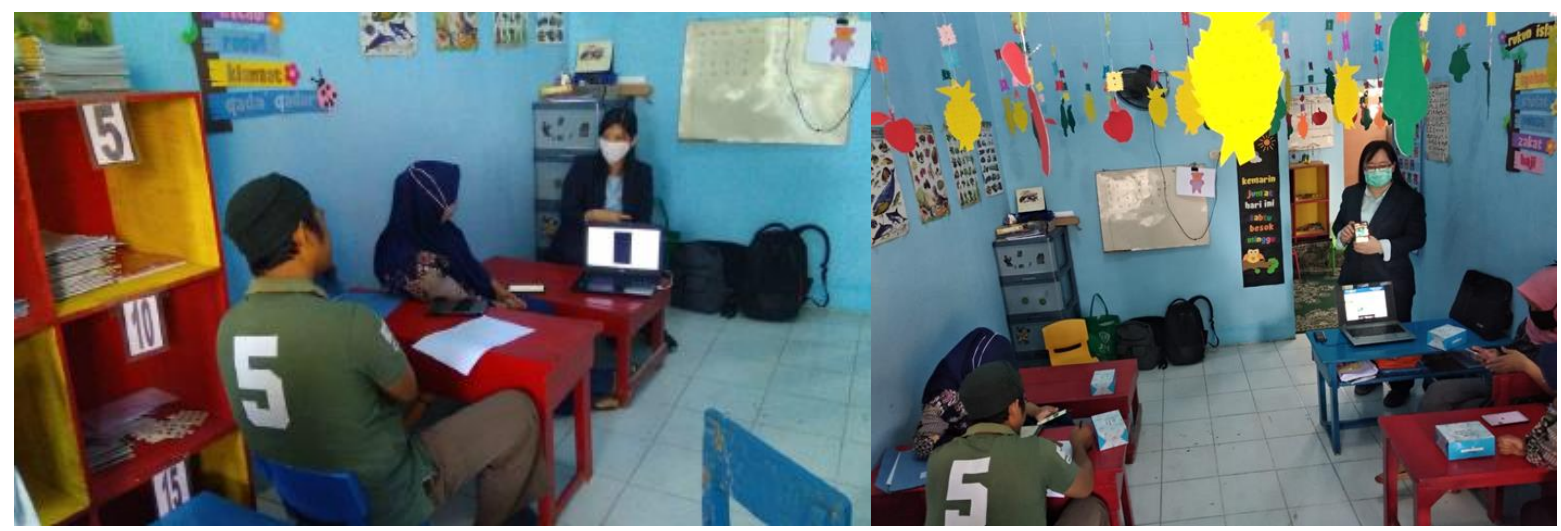

Gambar 1. Foto Pelatihan Berlangsung

Pelatihan memakan tambahan lebih banyak waktu dari jadwal yang sebelumnya dikarenakan aplikasi AZ Screen Recorder dan aplikasi Google meet masih awam bagi para peserta. Berikut beberapa foto setelah pelatihan dilaksanakan (Gambar 2).
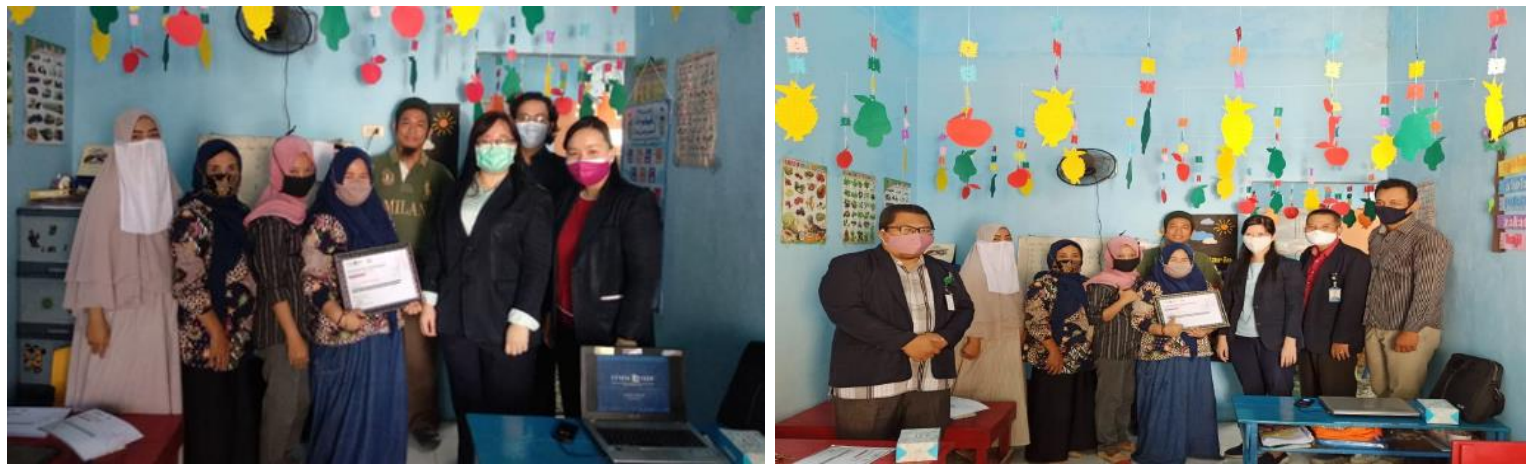

Gambar 2. Foto Bersama 
Elizabet, T., Pratama, D., Alamsyah, D., Yoannita, Y., Inayatullah, I., \& Tinaliah, T. (2021). Pelatihan aplikasi screen recorder dan video conference guna meningkatkan proses belajar mengajar. ABSYARA: Jurnal Pengabdian Pada Masyarakat, 2(1), 49-55. doi:10.29408/ab.v2i1.3495

Setelah 1 bulan dilaksanakannya pelatihan aplikasi screen recorder dan video conference pada TK Dewi Sartika Palembang, tim pelatih melakukan evaluasi hasil dari pelatihan yang dilaksanakan.

\section{PEMBAHASAN}

Dalam hasil evaluasi didapatkan bahwa para guru telah membuat video pembelajaran dan menggunakannya dalam proses belajar sehingga dapat disimpulkan bahwa melalui pelatihan ini dapat meningkatkan pemahaman guru dalam membuat video pembelajaran menggunakan aplikasi AZ Screen Recorder. Muhtarom, dkk. (2020) dalam penelitiannya juga menyetujui bahwa pelatihan dapat meningkatan pemahaman guru dalam membuat video pembelajaran menggunakan software/ aplikasi. Selain itu, melalui video yang telah dibuat oleh guru menggunakan aplikasi AZ screen recorder, siswa dapat lebih mudah mengingat dan memahami suatu pelajaran melalui video yang diberikan. Ini terbukti dimana setelah menonton video, siswa sanggup menjawab pertanyaan yang diberikan seputar video pembelajaran tersebut. Masih terdapat siswa yang kesulitan mengikuti pelajaran melalui aplikasi google meet dikarenakan kendala berupa sinyal internet yang kurang baik. Hal ini dapat teratasi melalui fitur record pada aplikasi google meet sehingga siswa dapat memutar kembali hasil rekaman pertemuan. Fitur record meeting ini juga merupakan fitur terpenting dan bermanfaat yang juga dirasakan oleh Fattah dan Azis (2020) yang meneliti tentang penggunaan fitur screen recorder. Berdasarkan penjelasan sebelumnya dapat diketahui bahwa pelatihan aplikasi screen recorder dan video conference yang telah diadakan ini memberikan hasil positif dan dapat meningkatkan proses belajar dan mengajar di TK Dewi Sartika

\section{SIMPULAN}

Hasil kegiatan pelatihan aplikasi Screen Recorder dan Video conference guna meningkatkan proses belajar mengajar adalah kegiatan pelatihan ini telah terlaksana dengan baik dan disambut baik oleh kepala sekolah, para pengajar, dan orang tua siswa TK Dewi Sartika Palembang. Kegiatan pelatihan ini dapat menambah pengetahuan bagi peserta khususnya para pengajar dan para siswa untuk menggunakan aplikasi AZ Screen Recorder dan Google Meet dalam proses belajar mengajar. Setelah pelatihan berakhir, banyak para pengajar yang telah menerapkan pelatihan ini dalam proses belajar mengajar dengan membuat video pembelajaran menggunakan aplikasi AZ Screen Recorder, dan melaksanakan pembelajaran menggunakan aplikasi video conference yaitu google meet yang memiliki fitur record/ rekam pertemuan sehingga bagi siswa yang tidak dapat mengikuti sesi video conference dikarenakan sinyal internet yang kurang baik dapat memutar kembali hasil rekaman dan tidak ketinggalan pelajaran

\section{PERNYATAAN PENULIS}

Artikel ini merupakan hasil karya sendiri yang belum pernah dipublikasikan baik secara keseluruhan maupun sebahagian, dalam bentuk jurnal, working paper atau bentuk lain yang dipublikasikan secara umum. Karya ilmiah ini sepenuhnya merupakan karya intelektual dan seluruh sumber yang menjadi rujukan dalam karya ilmiah ini telah sebutkan sesuai kaidah 
Elizabet, T., Pratama, D., Alamsyah, D., Yoannita, Y., Inayatullah, I., \& Tinaliah, T. (2021). Pelatihan aplikasi screen recorder dan video conference guna meningkatkan proses belajar mengajar. ABSYARA: Jurnal Pengabdian Pada Masyarakat, 2(1), 49-55. doi:10.29408/ab.v2i1.3495

akademik yang berlaku umum, termasuk para pihak yang telah memberikan kontribusi pemikiran pada isi, kecuali yang menyangkut ekspresi kalimat dan disain penulisan.

\section{DAFTAR PUSTAKA}

Arianti, B. D. D., \& Wirasasmita, R. H. (2020, May). WILMO (Web-based Interactive Learning Module), e-learning design for vocational school. In Journal of Physics: Conference Series (Vol. 1539, No. 1, p. 012045). IOP Publishing.

Fahruddin, F., \& Astini, B. N. (2018). Pelatihan program parenting untuk meningkatkan profesionalisme guru PAUD Di Kota Mataram Tahun 2018. Jurnal Pengabdian Magister Pendidikan IPA, 1(1). https://doi.org/10.29303/jpmpi.v1i1.206

Faradiba, F., Guswantoro, T., Lumbantobing, S. S., \& Malau, N. D. (2019). Pelatihan media pembelajaran kepada guru-guru yayasan pendidikan Muhammad Syatir Al-Ghazali Tangerang Selatan. JURNAL ComunitÃ Servizio: Jurnal Terkait Kegiatan Pengabdian kepada Masyarakat, terkhusus bidang Teknologi, Kewirausahaan dan Sosial Kemasyarakatan, 1(1), 28-36.

Fattah, F., \& Azis, H. (2020). Pemanfaatan video conference pada yayasan Sinergi Cendikia Makassar. Ilkomas, 1(2), 18-23.

Maulah, S., A, F. N., \& Ummah, N. R. (2020). Persepsi mahasiswa biologi terhadap perkuliahan daring sebagai sarana pembelajaran selama pandemi Covid-19. ALVEOLI: Jurnal Pendidikan Biologi, 1(2).

Muhtarom, Nizaruddin, \& Aryan Eka Prastya Nugraha. (2020). Pelatihan pembuatan media untuk pembelajaran jarak jauh. Jurnal Abdimas Bina Bangsa, 1(1). https://doi.org/10.46306/jabb.v1i1.19

Samsuri, T., Muliadi, A., Muhali, M., Asy’ari, M., Prayogi, S., \& Hunaepi, H. (2020). Pelatihan desain media interaktif pada pembelajaran daring bagi dosen pendidikan biologi. ABSYARA: Jurnal Pengabdian Pada Masyarakat, 1(2), 30-35. https://doi.org/10.29408/ab.v1i2.2745

Subekti, H. A., Nubaiti, N., Masilawati, M., \& Fitria, H. (2020). Pemanfaatan video conference sebagai media permbelajaran interaktif pada mata pelajaran produktif di Sekolah Menengah Kejuruan. Prosiding Seminar Nasional Program Pascasarjana Universitas PGRI Palembang.

Tafonao, T. (2018). Peranan media pembelajaran dalam meningkatkan minat belajar mahasiswa. Jurnal Komunikasi Pendidikan, 2(2). https://doi.org/10.32585/jkp.v2i2.113

Yudianto, A. (2017). Penerapan video sebagai media pembelajaran. Seminar Nasional Pendidikan 2017.

Zaini, H., \& Dewi, K. (2017). Pentingnya media pembelajaran untuk anak usia dini. Raudhatul Athfal: Jurnal Pendidikan Islam Anak Usia Dini, 1(1). https://doi.org/10.19109/ra.v1i1.1489 